$\sqrt{B}$

J. bio-sci. 14: 127-130, 2006

ISSN 1023-8654

\title{
EFFECT OF PLANTING METHOD AND NITROGEN LEVELS ON THE YIELD AND YIELD ATTRIBUTES OF WHEAT
}

\author{
${ }^{1}$ Md llias Hossain, Regional Wheat Research Centre, Shyampur, Rajshahi \\ ${ }^{2}$ Md Khairul Islam*, Dept. of Crop Science and Technology, Faculty of Agriculture, University of Rajshahi, \\ ${ }^{3}$ Md Abu Sufian, Wheat Research Centre, Dinajpur \\ ${ }^{4}$ Cracg A Meisner, Wheat Specialist in Bangladesh and Cornell University adjunct Professor \\ ${ }^{5} \mathrm{Md}$ Sayeedul Islam, Dept. of Genetics and Breeding, Faculty of Agriculture, \\ University of Rajshahi, Bangladesh
}

\begin{abstract}
A field trial was conducted during the winter season of 2001-2002 to find out the effect of planting method and nitrogen levels on wheat. Effects of two planting methods viz. bed planting and conventional planting were studied on three nitrogen levels viz. 50, $100 \& 150 \mathrm{~kg} /$ ha on wheat (var. Protiva). Planting methods exhibited significant variation in respect of all the characters studied. The maximum grain yield (3.60 t/ha) was obtained from bed planting. Different levels of nitrogen significantly influenced on yield and yield attributing parameters of wheat. The highest grain yield $(3.70 \mathrm{t} / \mathrm{ha})$ was recorded from $150 \mathrm{~kg}$ $\mathrm{N}$ per hectare. The interaction effects of planting methods and nitrogen levels showed the significant difference in respect of spike/m², spike length and grain yield. Highest grain yield (4.04 t/ha) was obtained at bed planting using $150 \mathrm{~kg} \mathrm{~N}$ per hectare. Though higher rate of $\mathrm{N}$ are used but lodging of plant height was not noticed. The correlation analyses showed that the rate of change of grain yield was highly dependent upon the rate of change of yield contributing characters of wheat.
\end{abstract}

Key words: Planting methods, Nitrogen, Wheat, Cropping system.

\section{Introduction}

Rice-wheat is a major cropping system in Bangladesh. These two crops are grown in sequence in one calendar year where rice during wet rainy season and wheat relatively dry and cool winter season. Due to introduction of high yielding varieties of rice and wheat, double cropping of these two crops become feasible. Area and productivity under the two crops are being increased day by day (Hobbs and Morris 1996). In high productivity, irrigated areas, rice is transplanted after puddling the fields (ploughing wheat fields are saturated). This practice destroys the soil physical properties that have the implications of wheat crop (Hobbs et al. 2000). In addition, under the changing socio-economic environment of our country, workers are not available or reluctant to undertake tedious agricultural operations. These situations also produce labor shortages and further escalating labor costs. Alternate methods of establishing crops, especially this cropping sequence, requiring less labor, water, fertilizer etc. without sacrificing productivity are needed. The suitable planting method, especially bed planting has been shown to improve water distribution and efficiency, fertilizer use efficiency, reduced weed infestation and lodging and it also reduces seed rate without sacrificing yield (Hobbs et al. 2000). It is extensively used in obtaining high yielding; irrigation wheat growing areas in Mexico (Limon et al. 2000), and use of this practice has increased dramatically in the last decade (Meisner et al. 1992). The information available so far, regarding this practice is inadequate in Bangladesh and nitrogen fertilizer strongly influenced on yield and yield attributing characters of wheat. Therefore, the present work has been undertaken for determining suitable planting method and optimal quantity of nitrogen fertilizer for increasing yield and keeping the soil fertility over the long term.

\footnotetext{
${ }^{*}$ Corresponding author.
} 


\section{Materials and Methods}

The experiment was carried out at the research field of Regional Wheat Research Center of BARI, Shyampur, Rajshahi, Bangladesh during the winter season of 2001-2002 using wheat variety Protiva. The experimental site was a medium high land and the $\mathrm{pH}$ of the soil was 7.6 with organic matter content of $0.8 \%$. It also had low amount of nitrogen $(0.07 \%)$, phosphorus $(7.16 \mathrm{ppm})$, potassium $(0.29 \mathrm{meg} / 100 \mathrm{~g}$ soil) and sulfur $(2.86 \mathrm{ppm})$ supply capacity. Texturally the soil was silty clay loam and neutral in nature (BARC 1997).

There were six treatment combinations consisting of two levels of planting methods viz. bed planting and conventional planting and three levels of nitrogen (viz. 50, 100 and $150 \mathrm{~kg} / \mathrm{ha}$ ). Bed (row to row distant, 30 $\mathrm{cm}$ ) and conventional (row to row distant, $20 \mathrm{~cm}$ ) plantings are the method of continuous sowing by bed planter machine in bed and continuous sowing by hand in conventional system. A normal dose of phosphorus $(60 \mathrm{~kg} / \mathrm{ha}$ ) from triple super phosphate, potassium $(40 \mathrm{~kg} / \mathrm{ha}$ ) from muriate of potash and sulfur (45 kg/ha) from gypsum and the two-third (2/3) of nitrogen were applied during final land preparation. The remaining nitrogen was top dressed at CRI (Crown Root Initiation) stage followed by 1st irrigation. The experiment was laid out in split plot design with three replications. The planting method was set up in main plot and $\mathrm{N}$ levels in sub plot. The plot dimension was $5 \mathrm{~m} \times 3 \mathrm{~m}$. Seeds were sown on $27^{\text {th }}$ November 2001 . Irrigation was applied just to fill the furrow in all the treatments. Three irrigations were done in this trial. First, second and third irrigations were given in CRI, tillering and panicle initiation stages with the supply of 240 litre/15 $\mathrm{m}^{2}$ in bed and 320 litre/ $15 \mathrm{~m}^{2}$ in conventional tilled flat methods, respectively. One weeding was given after first irrigation on December 22, 2001. Finally, harvesting was accomplished on March 27, 2002. During the tenure period of investigation, there existed the average minimum and maximum temperature (17.73$\left.29.45^{\circ} \mathrm{C}\right)$, rainfall $(13.0-18.3 \mathrm{~mm})$ and relative humidity $(77.52-91.38 \%)$, respectively. Data were collected from $15 \mathrm{~m}^{2}$ (whole plot) of each plot and statistically analyzed. LSD was used to determine the significant difference between treatments.

\section{Results and Discussion}

\section{Effects of planting method}

Methods of planting were found significant on yield and yield contributing characters of wheat and the results are presented in Table 1. Bed planting produced more number of plants and spikes per square meter, longer spike length and maximum grain weight than conventional methods. Grain yield also showed highest in bed planting due to higher yield attributes. Similar trend was followed in case of straw yield. Meisner et al. (1992) reported that the growth and grain yield of wheat were significantly influenced by planting methods. Sayre et al. (1997) had the similar observation when they worked with different planting methods. These results are in agreement with the findings of Hobbs et al. (2000).

Table 1. Effect of methods of planting on yield and yield contributing characters of wheat.

\begin{tabular}{l|c|c|c|c|c|c|c|c}
\hline Treatments & $\begin{array}{c}\text { Initial } \\
\text { plants } / \mathrm{m}^{2}\end{array}$ & Spike/m² & $\begin{array}{c}\text { Spike length } \\
(\mathrm{cm})\end{array}$ & $\begin{array}{c}\text { Grains/ } \\
\text { spike }\end{array}$ & $\begin{array}{c}1000 \text { grain } \\
\text { wt. }(\mathrm{g})\end{array}$ & $\begin{array}{c}\text { Grain yield } \\
(\mathrm{t} / \mathrm{ha})\end{array}$ & $\begin{array}{c}\text { Straw } \\
\text { yield }(\mathrm{t} / \mathrm{ha})\end{array}$ & $\mathrm{HI}(\%)$ \\
\hline $\begin{array}{l}\text { Bed planting } \\
\begin{array}{l}\text { Conventional } \\
\text { planting }\end{array}\end{array}$ & 228 & 340 & 9.8 & 45.7 & 45.9 & 3.60 & 4.78 & 42.84 \\
\hline LSD $(0.05)$ & 6.78 & 283 & 8.8 & 40.3 & 42.7 & 3.17 & 4.62 & 40.67 \\
\hline CV $(\%)$ & 2.54 & 4.07 & 3.21 & 3.99 & 2.28 & 3.94 & 3.37 & 4.71 \\
\hline
\end{tabular}

Means having same letter (s) do not differ significantly at $5 \%$ level of probability 


\section{Effects of Nitrogen levels}

Nitrogen levels were significantly influenced in all the parameters studied and the results are presented in Table 2. Nitrogen dose at $150 \mathrm{~kg} / \mathrm{ha}$ gave more number of plants and spikes per square meter, longer spike length and higher grain weight. There was trend to increase grain yield with the increase of $\mathrm{N}$ levels. The entire yield attributes affected grain yield. Similar trend was followed in case of straw yield. Sayre (2000) denoted that the yield and yield attributes of wheat was positively enhanced by different doses of nitrogen. These results are strongly supported by the findings of Limon et al. (2000).

Table 2. Effect of N-levels on yields and yields attributing characters of wheat.

\begin{tabular}{cccccccccccc}
\hline $\begin{array}{c}\text { Treatments } \\
(\mathrm{Kg} \mathrm{N} / \mathrm{ha})\end{array}$ & $\begin{array}{c}\text { Initial } \\
\text { plants/m² }\end{array}$ & Spikes $/ \mathrm{m}^{2}$ & $\begin{array}{c}\text { Spike } \\
\text { length }(\mathrm{cm})\end{array}$ & $\begin{array}{c}\text { Grains/ } \\
\text { Spike }\end{array}$ & $\begin{array}{c}1000 \text { grain } \\
\text { wt. (g) }\end{array}$ & $\begin{array}{c}\text { Grain } \\
\text { yield (t/ha) }\end{array}$ & $\begin{array}{c}\text { Straw } \\
\text { yield (t/ha) })\end{array}$ & HI (\%) \\
\hline 50 & $191 \mathrm{c}$ & $268 \mathrm{c}$ & $9.05 \mathrm{c}$ & $40 \mathrm{c}$ & $43.6 \mathrm{~b}$ & $2.98 \mathrm{c}$ & $4.54 \mathrm{c}$ & $39.65 \mathrm{c}$ \\
100 & $219 \mathrm{~b}$ & $305 \mathrm{~b}$ & $9.36 \mathrm{~b}$ & $42 \mathrm{~b}$ & $43.7 \mathrm{~b}$ & $3.47 \mathrm{~b}$ & $4.72 \mathrm{~b}$ & $42.33 \mathrm{~b}$ \\
150 & $243 \mathrm{a}$ & $330 \mathrm{a}$ & $9.78 \mathrm{a}$ & $44 \mathrm{a}$ & $46.8 \mathrm{a}$ & $3.70 \mathrm{a}$ & $4.83 \mathrm{a}$ & $43.29 \mathrm{a}$ \\
\hline LSD (0.05) & 4.801 & 11.00 & 0.259 & 1.48 & 0.87 & 0.11 & 0.276 & 1.45 \\
\hline CV (\%) & 2.54 & 4.07 & 3.21 & 3.99 & 2.28 & 3.94 & 3.37 & 4.71 \\
\hline
\end{tabular}

Means having same letter (s) do not differ significantly at $5 \%$ level of probability

\section{Interaction effects}

Planting methods and N-levels were statistically significant in almost all the treatment combinations except grains per spike and straw yield (Table 3). The treatment combination of bed planting and $150 \mathrm{~kg} \mathrm{~N} / \mathrm{ha}$ showed highest plants $/ \mathrm{m}^{2}$. Similar trend was followed in case of spikes/ $\mathrm{m}^{2}$. Higher length of spikes was obtained from bed planting with $150 \mathrm{~kg} / \mathrm{ha} \mathrm{N}$, but statistically at par to conventional method of same amount of $\mathrm{N}$ level. Though grains /spike were not significantly influenced by $\mathrm{N}$ levels, but with the increase of $\mathrm{N}$ levels increase of grain /spike was found. Highest grain weight was recorded from higher doses of $\mathrm{N}$ in bed planting. All the yield attributes contributed highest grain yield in treatments combination (bed planting \& 150 $\mathrm{kg} \mathrm{N} / \mathrm{ha}$ ). Grain yield was increased with the increase of $\mathrm{N}$ levels in case of bed planting. But grain yield was statistically at par in conventional method of all levels of N. Grain yield was not statistically influenced with increase or decrease of $\mathrm{N}$ levels. Straw yield was not significantly influenced, but higher trend was found with higher dose of N. These results are in agreement with the findings of Sayre (2000) when they worked with planting methods and nitrogen levels.

From one year result it showed that higher grain yield of wheat could be achieved with bed planting system and applied $150 \mathrm{~kg} \mathrm{~N} / \mathrm{ha}$ for Rajshahi region.

Table 3. Interaction effect of method of planting and N-levels (Kg/ha) on yield and yield attributing characters of wheat.

\begin{tabular}{|c|c|c|c|c|c|c|c|c|c|}
\hline \multirow{2}{*}{\multicolumn{2}{|c|}{$\begin{array}{c}\text { Treatment combinations } \\
\text { (Planting methods } \times \\
\text { N levels) }\end{array}$}} & \multirow{2}{*}{$\begin{array}{l}\text { Initial plants } \\
\text { /m2 }\end{array}$} & \multirow[t]{2}{*}{ Spikes/m2 } & \multirow{2}{*}{$\begin{array}{c}\text { Spike } \\
\text { length }(\mathrm{cm})\end{array}$} & \multirow{2}{*}{$\begin{array}{l}\text { Grains/ } \\
\text { spike }\end{array}$} & \multirow{2}{*}{$\begin{array}{c}\text { 1000-grain } \\
\text { wt.(g) }\end{array}$} & \multirow{2}{*}{$\begin{array}{c}\text { Grains } \\
\text { yield (t/ha) }\end{array}$} & \multirow{2}{*}{$\begin{array}{l}\text { Straw yield } \\
\text { (t/ha) }\end{array}$} & \multirow[t]{2}{*}{$\mathrm{HI}(\%)$} \\
\hline & & & & & & & & & \\
\hline \multirow{3}{*}{ Bed } & 50 & $201.7 d$ & $284 \mathrm{C}$ & $9.2 \mathrm{~cd}$ & 42.4 & $45.0 \mathrm{bc}$ & $3.08 d$ & 4.60 & $40.10 d$ \\
\hline & 100 & $229.7 \mathrm{~b}$ & $325 b$ & $9.4 \mathrm{bc}$ & 45.9 & $45.9 \mathrm{~b}$ & $3.68 b$ & 4.82 & $43.29 \mathrm{~b}$ \\
\hline & 150 & $254.3 \mathrm{a}$ & $363 a$ & $9.9 \mathrm{a}$ & 48.8 & $49.6 \mathrm{a}$ & $4.04 \mathrm{a}$ & 4.91 & $45.14 \mathrm{a}$ \\
\hline \multirow{5}{*}{ Conventional } & 50 & $181.7 \mathrm{e}$ & $253 d$ & $8.8 \mathrm{~d}$ & 38.2 & $42.3 d$ & $2.89 \mathrm{e}$ & 4.48 & $39.21 \mathrm{e}$ \\
\hline & 100 & $209.2 \mathrm{C}$ & $285 \mathrm{C}$ & $9.2 \mathrm{~cd}$ & 40.3 & $41.6 \mathrm{~d}$ & $3.26 \mathrm{c}$ & 4.62 & $41.37 \mathrm{C}$ \\
\hline & 150 & $232.7 \mathrm{~b}$ & $298 \mathrm{C}$ & $9.6 \mathrm{ab}$ & 42.5 & $44.0 \mathrm{C}$ & $3.36 \mathrm{c}$ & 4.75 & $41.43 c$ \\
\hline & $\operatorname{LSD}(0.05)$ & 6.789 & 15.5 & 0.36 & NS & 1.24 & 0.16 & NS & 2.06 \\
\hline & $\mathrm{CV}(\%)$ & 2.54 & 4.07 & 3.21 & 3.99 & 2.28 & 3.94 & 3.37 & 4.71 \\
\hline
\end{tabular}

Means having same letter (s) do not differ significantly at $5 \%$ level of probability 
Table 4. Correlation coefficient among the yield components and grain yield of wheat.

\begin{tabular}{|c|c|c|c|c|c|}
\hline Plant characters & Initial plants/m2 & Spikes/m2 & Spike length $(\mathrm{cm})$ & Grains/spike & 1000-grain wt.(g) \\
\hline Spikes/m2 & $0.943846^{* * *}$ & 1 & & & \\
\hline Spike length (cm) & $0.982607^{* * *}$ & $0.913579^{* * *}$ & 1 & & \\
\hline Grains/spike & $0.902222^{* * *}$ & $0.980323^{\star \star *}$ & $0.8783182^{* \star *}$ & 1 & \\
\hline 1000-grain wt.(g) & $0.783892^{* * *}$ & $0.900676^{\star * *}$ & $0.7940823^{\star * *}$ & $0.94525581^{* * *}$ & 1 \\
\hline Grains yield (t/ha) & $0.94531^{* * *}$ & $0.989001^{* * *}$ & $0.8943284^{* * *}$ & $0.94896265^{\star * *}$ & $0.8438539 * * *$ \\
\hline
\end{tabular}

${ }^{* * \star}$ indicates significant at $0.1 \%$ level according to correlation coefficient test.

\section{Correlation and regression analyses}

Correlation estimation was accomplished at phenotypic level and the results obtained are presented in Table 4. The values of correlation denoted that grain yield (t/ha) showed significant positive correlation with initial plants $/ \mathrm{m} 2\left(r=0.9451^{\star \star *}\right)$, spikes $/ \mathrm{m} 2\left(r=0.989001^{\star \star *}\right)$, spike length $\left(r=0.8943284^{\star \star \star}\right)$, grains $/$ spike $\left(\mathrm{r}=0.94896265^{* * *}\right)$, and 1000-grain wt. $\left(\mathrm{r}=0.8438539^{* * *}\right)$. In addition, these characters were also intercorrelated among themselves. Similar correlation trend was reported by Limon et al. (2000).

\section{Acknowledgements}

The authors express their sincere thanks to Dr A K M Rafiul Islam, Professor, Department of Botany, University of Rajshahi, for his valuable suggestion and preparing this article.

\section{References}

BARC (1997) Fertilizer Recommendations Guide, Dhaka. Bangladesh.

Hobbs P R and Morris (1996) Meeting of South Asia future food requirements from rice-wheat cropping system: Priority issues facing researchers in the post green revolution era, NRG Paper 96-101, Mexico. DF. CIMMYT.

Hobbs P R Y, Sing G S, Giri J G Lauren and J M Dusbury (2000) Direct seeding and reduced tillage options in the ricewheat systems of the Indo-Gangetic plain of South Asia. Paper presented at IRRI workshop, Bankok, Thailand, 2528 January, 2000.

Limon O A L, Sayre K D and C A Francis (2000) Wheat nitrogen use efficiency in a bed planting system in Northwest Mexico. Agron. J. 92: 303-308.

Meisner C A E, Acervedo D, Flores K, Sayre L, Ortizmonasterio and D Byerlee (1992) Wheat production and grower practices in the Yaqui Valley, Sonora, Mexico. Wheat Special Report. No. 6. Mexico, D F CIMMYT.

Sayre K D and O H Morens Romos (1997) Application of raised bed planting system to wheat. Wheat Program Special Res.31. CIMMYT, Mexico. P $14-22$.

Sayre K D (2000) Effect of tillage, crop retention and nitrogen management on the performance of bed planted, furrow irrigated spring wheat in Northwest Mexico. In Proc. 15th cont. Int. Soil Tillage Res. Org, 2-7 July 2000.

\section{cWiYZ}

